\title{
Correction to: Preserving the Knowledge of the Past Through Virtual Visits: From 3D Laser Scanning to Virtual Reality Visualisation at the Istanbul Çatalca İnceğiz Caves
}

\author{
Gürcan Büyüksalih ${ }^{1} \mathbb{D} \cdot$ Tuna Kan $^{1} \cdot$ Gözde Enç Özkan ${ }^{1} \cdot$ Müge Meriç ${ }^{1} \cdot$ Lale Isın $^{1} \cdot$ Thomas P. Kersten $^{2}$ D
}

Published online: 9 April 2021

(c) Deutsche Gesellschaft für Photogrammetrie, Fernerkundung und Geoinformation (DGPF) e.V. 2021

\section{Correction to: PFG (2020) 88:133-146 \\ https://doi.org/10.1007/s41064-020-00091-3}

The article Preserving the Knowledge of the Past Through Virtual Visits: From 3D Laser Scanning to Virtual Reality Visualisation at the Istanbul Çatalca İnceğiz Caves, written by Gürcan Büyüksalih, Tuna Kan, Gözde Enç Özkan, Müge Meriç, Lale Isın and Thomas P. Kersten was originally published Online First without Open Access. After publication in volume 88 , issue 2, page 133-146 the author decided to opt for Open Choice and to make the article an Open Access publication. Therefore, the copyright of the article has been changed to $($ C The author(s) 2020 and the article is forthwith distributed under the terms of the Creative Commons Attribution.

The original article can be found online at https://doi.org/10.1007/ s41064-020-00091-3.

Thomas P. Kersten

Thomas.Kersten@hcu-hamburg.de

Gürcan Büyüksalih

gbuyuksalih@yahoo.com

Tuna Kan

tuna.kan@bimtas.istanbul

Gözde Enç Özkan

gozde.encozkan@bimtas.istanbul

Müge Meriç

muge.meric@bimtas.istanbul

Lale Isin

laleisin@bimtas.istanbul

1 Boğaziçi İnşaat Müşavirlik A.Ş. (BIMTAŞ), Evliya Celebi Mah. Mesrutiyet Cad. Eski TÜYAP Binasi No. 50, 34430

Tepebaş1 - Beyoğlu, Istanbul, Turkey

2 Photogrammetry \& Laser Scanning Lab, HafenCity University Hamburg, Überseeallee 16, 20457 Hamburg, Germany 